\title{
生分解性乳酸・グリコール酸共重合体（PLGA）ナノ粒子の植物細胞への送達
}

\author{
佐藤 美咲, 愛須 光, 湯浅 友貴, 吉原 章仙, 小西 康裕, 野村 俊之*
}

\section{Delivery of Biodegradable Poly Lactic-co-Glycolic Acid (PLGA) Nanoparticles into Plant Cells}

\author{
Misaki Sato, Hikaru Aisu, Tomoki Yuasa, Akinori Yoshihara, Yasuhiro Konishi and Toshiyuki Nomura*
}

Received 17 January 2020; Accepted 21 February 2020

\begin{abstract}
The behavior of biodegradable poly lactic-co-glycolic acid (PLGA) nanoparticles (NPs) toward plant cells was investigated using confocal laser microscopy when exposed to leaves and roots of Arabidopsis thaliana. As a result, when the leaves were exposed to the PLGA NP suspension by applying pressure, the suspension penetrated into the leaves through the stomata, and the NPs were taken into the mesophyll cells. In contrast, PLGA NPs were taken into the cells of root tip and root hair with thin cell wall. These experimental results suggest that the PLGA NPs are suitable for delivery of useful substances into plant cells.
\end{abstract}

Keywords: Arabidopsis thaliana, Delivery, Carrier nanoparticles, Plant cells, Poly lactic-co-glycolic acid.

\section{1. 緒言}

世界の人口は 2050 年までに 90 億人を突破すると予測 されており，現状より少なくとも50\%以上の食糧増産が 必要とされている[1]。しかし, 可食作物の約 40\%は病害 により損失しているのが現状である[2]。現在，これら植 物病害を防除するために農薬が使用されているが, 揮発, 光分解, 流出などによりターゲットである病原菌に到達 する農薬は $0.1 \%$ 以下といわれている[3]。このため, 農薬 を繰り返し散布しなくてはならず，土䁃や水質污染の原 因となっている $[4]$ 。

近年, 薬物や遺伝子を封入したナノ粒子を用いたドラッ グデリバリーシステムが注目されている。ナノ粒子を用 いることで薬物の徐放性, ターゲットとの特異的結合性, 遺伝子の保護といった効果があり, 安全かつ簡便な手法 として期待されている[5-7]。実際，動物細胞ではナノ粒 子を用いた研究が精力的に行われているが, 細胞壁を備 えた植物や植物病原菌に目的物質が導入された事例はき わめて少ない。筆者らは, 農薬を封入した乳酸・グリコー ル酸共重合体（PLGA）ナノ粒子を用いると, 細胞壁を もつジャガイモ疫病菌の細胞内部に農薬を送達でき, 植 物病害が予防できることを明らかにしている[8]。沼田ら は，カチオン性の細胞膜透過性ペプチドを用いた植物へ

\footnotetext{
粉体工学会 2019 年度秋期研究発表会 BP 賞受賞研究 大阪府立大学大学院 工学研究科 化学工学分野

（５ 599-8531 大阪府堺市中区学園町 1-1）

Department of Chemical Engineering, Osaka Prefecture University

(1-1, Gakuen-cho, Naka-ku, Sakai, Osaka 599-8531, Japan)

* Corresponding Author nomura@chemeng.osakafu-u.ac.jp
}

の遺伝子導入について報告している[9]。

一方で, 商業的に栽培されている植物に遺伝子操作を 行い, 新たな遺伝子を発現させたり, 遺伝子発現を促進・ 抑制したりすることで，除草剤の影響を受けない作物， 害虫に対する抵抗性を持つ作物, 栄養価の高い作物など の栽培が可能となる $[10]$ 。このような遺伝子組換作物の 栽培面積は年々増加しており, 今後も増加が見込まれる [11]。また，植物工場では養液栽培により植物を生育し ているが，養分をナノ化することで選択的に送達するこ とができれば, 雑菌のコンタミネーションにも強い効率 的な栽培システムが期待できる。したがって, 遺伝子, 薬物, 農薬, 養分などの目的物質をナノ粒子に封入し, 植物に直接送達する簡便な方法が確立できれば, 食糧増 産に貢献できる有効な技術となることが期待される。

そこで本研究では，モデル植物としてよく用いられる シロイヌナズナの葉と根にPLGAナノ粒子を暴露したと きのナノ粒子の挙動について, 共焦点レーザー顕微鏡 （CLSM）を用いた直接観察による実験的検討を行った。

\section{2. 実験方法}

\section{1 実験に用いた植物}

モデル植物として, アブラナ科のシロイヌナズナ (Arabidopsis thaliana) を用いた。タッパーにロックウー ルブロックを入れて熱湯に 5 分間浸漬し, これを 3 回繰 り返してから純水で洗浄した。シロイヌナズナの種を各 ブロックの中央部に爪楊枝で置き, ブロックが半分程度 浸かるようにタッパーに純水を注いだ。そして，ブロッ ク表面が乾燥しないようにタッパーにラップを被せ, $23^{\circ} \mathrm{C}$ のグロースチャンバー内において長日条件下（明期 

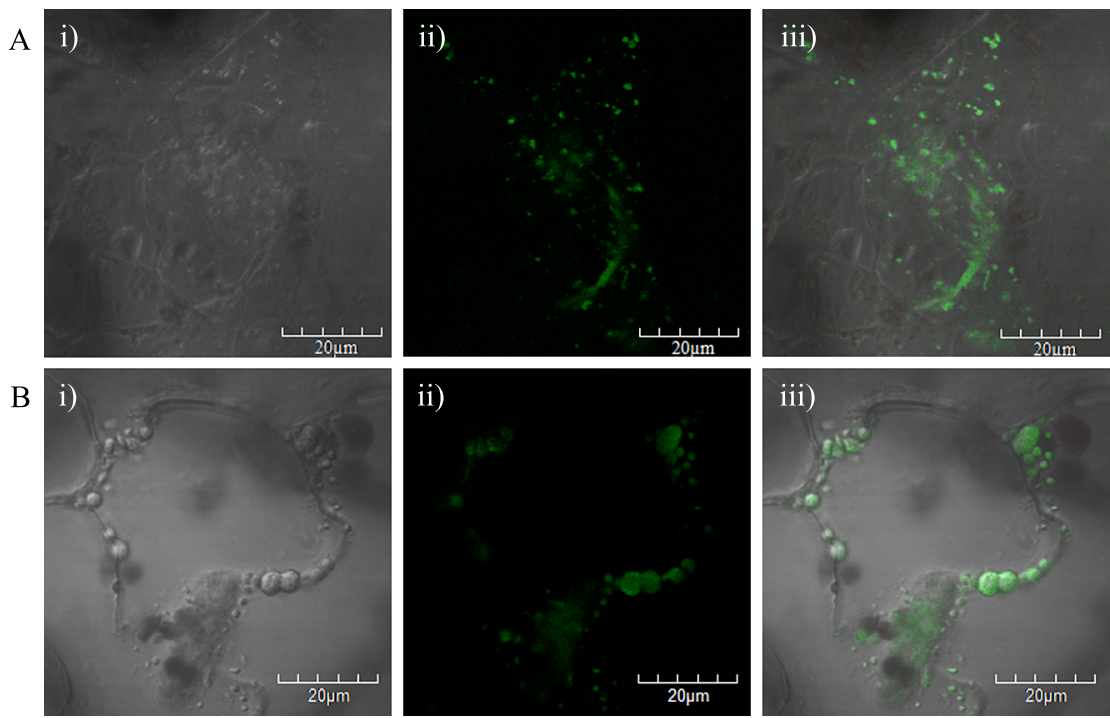

Fig. 1 Confocal images of (A) intercellular space and (B) mesophyll cell inside the Arabidopsis leaf exposed to PLGA NP suspension. (i) DIC image, (ii) PLGA labeled with Coumarin 6, and (iii) merged image of (i)-(ii)

16 時間，暗期 8 時間）で生育した。種が発芽したらラッ プを取り除き，希釈したハイポネックス原液を定期的に 追加した。

\section{2 実験に用いた PLGA ナノ粒子}

植物に暴露したナノ粒子の局在を CLSM で観察するた めに, エマルション溶媒拡散法[12-14]により蛍光標識し たPLGA ナノ粒子を合成した。 $2 \mathrm{w} / \mathrm{v} \%$ ポリビニルアル コール水溶液 $50 \mathrm{~mL}$ に, $50 \mathrm{mg}$ の PLGA（シグマアルド リッチ, 分子量 7,000〜17,000, 乳酸：グリコール酸 $=$ 50:50）と $2 \mu \mathrm{g}$ のクマリン 6 を溶解したアセトン溶液 $1 \mathrm{~mL}$ を滴下し，スターラーを用いて $500 \mathrm{rpm}$, 室温で一晚擋 拌した。得られたPLGA ナノ粒子は未封入のクマリン 6 を除去した後，純水に再分散してから実験に用いた。合 成したPLGA ナノ粒子の粒子径とゼー夕電位は, ゼー夕 電位・粒径測定システム（大塚電子, ELS-Z）を用いて 測定した結果，中位径は $113 \pm 8 \mathrm{~nm}$, ゼー夕電位は $-21 \pm 1 \mathrm{mV}$ であった。

\section{3 ナノ粒子の植物への暴露}

ナノ粒子の植物の葉への暴露は, 既往の報告[9]に基づ いて行った。約 5 週間生育させたシロイヌナズナの葉を 採取し，針なしシリンジを用いて PLGA 粒子懸濁液 $0.1 \mathrm{~mL}$ を葉の裏側に強く押しつけながらゆっくりと押し 出した。室温下で 30 分間静置後, リン酸緩衝生理食塩水 (PBS) バッファーで洗浄してからスライドガラスに葉を 置き, CLSM（オリンパス, FV-1000D）を用いてナノ粒 子の局在を直接観察した。また, シロイヌナズナの根は, 水を注いだシャーレに種を入れ，発芽して根の長さが約 $2 \mathrm{~cm}$ に伸長したものを採取し, スライドガラス上で PLGA 粒子懸濁液を暴露した。

\section{3. 実験結果および考察}

シロイヌナズナの葉の裏側に PLGA ナノ粒子を暴露し
たときの CLSM 像を Fig. 1 に示す。ナノ粒子の局在には 2 種類のパターンがあることがわかった。Fig. 1A では, 葉の内部にもかかわらず, 多数のナノ粒子がブラウン運 動していることが観察された。一方, Fig. 1Bでは, 細胞 内にナノ粒子が取り込まれ, 小胞に集積していることが わかった。なお，ナノ粒子が取り达まれた細胞はごく一 部で, 取り込まれたナノ粒子がブラウン運動している様 子は観察されなかった。加えて, 葉の表面にPLGA 粒子 懸濁液を滴下して静置しただけでは，葉の内部へのナノ 粒子の取込は観察されなかった。植物の葉の表皮細胞の 内側には葉肉細胞があり, 葉緑体により光合成が行われ ているが, 細胞が密に詰まっているわけではなく, 細胞 間隙と呼ばれる気体で満たされた空間が存在する。また, 葉の表面における水の接触角は約 $97^{\circ}[15]$ であることから 疎水性である。これらのことから, 葉の表面に粒子懸濁 液を滴下しただけでは, 葉の内部に懸濁液が浸入するこ とができなかったと考えられる。したがって，圧力をか けながら粒子懸濁液を暴露すると, 気孔から懸濁液が細 胞間隙に浸入することができ，PLGA ナノ粒子がブラウ ン運動していたものと考えられる。その後, 葉の内部に 侵入した懸濁液に含まれるナノ粒子が葉肉細胞に取り込 まれて小胞に集積したものと推察される。

次に, シロイヌナズナの根に PLGA ナノ粒子を暴露し たときの CLSM 像を Fig. 2 に示す。シロイヌナズナの根 では, その先端の細胞に PLGAナノ粒子が取り込まれて いることがわかった（Fig. 2A）。これは, 根の先端に存 在する細胞は根冠と呼ばれる細胞で, 根が伸長するにつ れて内側から供給される新しい細胞のために細胞壁が数 $10 \mathrm{~nm}$ と薄く, ナノ粒子が取り込まれやすかったと推察 される。一方, 根の中間部ではナノ粒子はほとんど取り 込まれていなかった（Fig. 2B）。しかし, 中間部の表皮 細胞が外側に向かって管状に伸長した根毛では, ナノ粒 

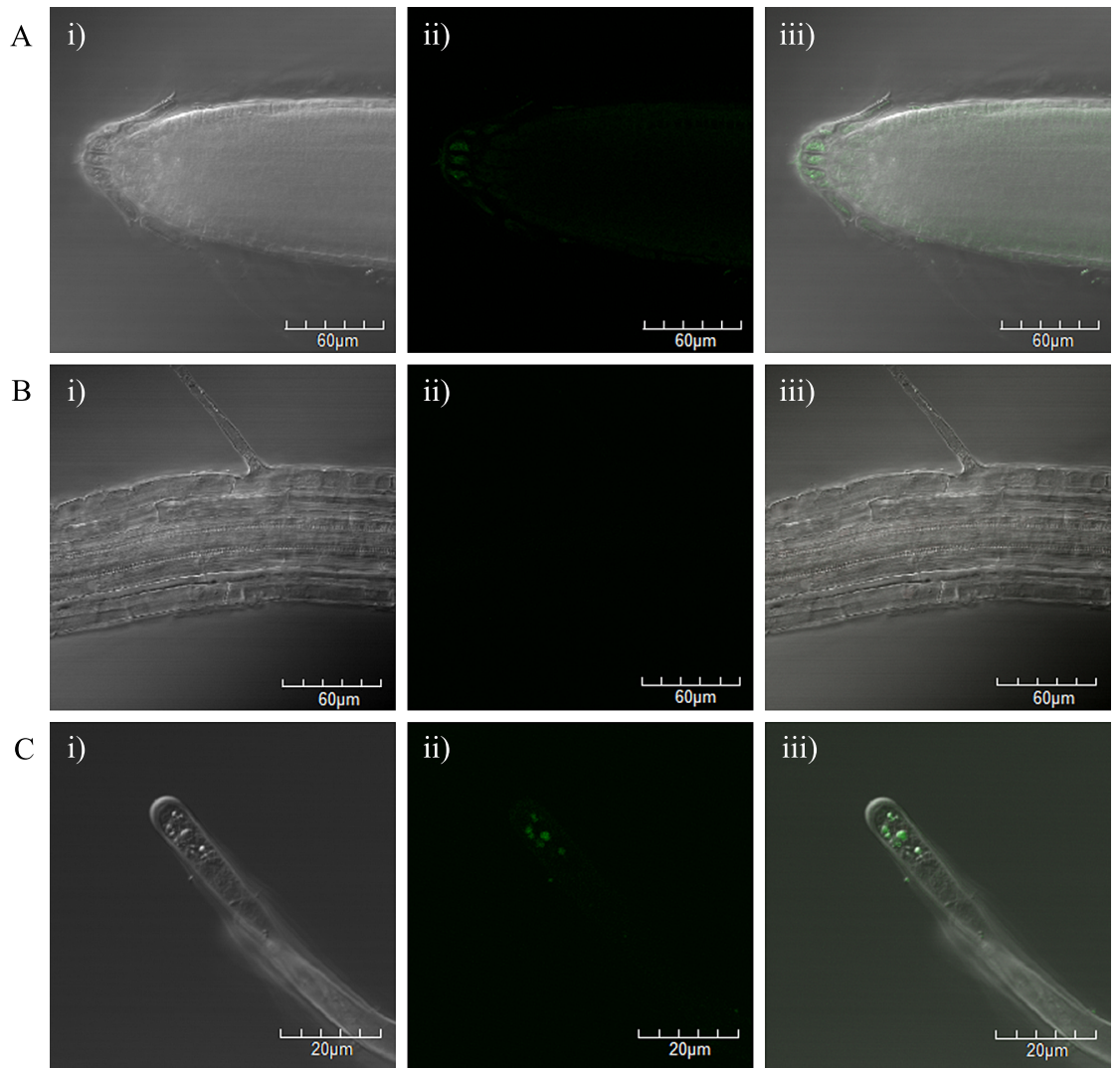

Fig. 2 Confocal images of (A) root tip, (B) intermediate part of the root, and (C) root hair of the Arabidopsis root exposed to PLGA NP suspension. (i) DIC image, (ii) PLGA labeled with Coumarin 6, and (iii) merged image of (i)-(ii)

子が内部に局在していることがわかった（Fig. 2C）。根 毛は維管束植物の仮根で水や栄養分の吸収作用を担って おり, 表皮細胞の細胞壁 $0.1 \sim 1 \mu \mathrm{m}$ と比べて数 $10 \mathrm{~nm}$ と 薄い[16]ため, ナノ粒子が取り込まれたと考えられる。

PLGA ナノ粒子は負に带電していて, 同じく負に带電 した細胞との間には静電斥力が作用するにもかかわらず, 一部の細胞内に取り込まれたのは，既報における細胞壁 を備えた酵母細胞（厚さ：約 $100 \mathrm{~nm}$ ）[17]や植物病原菌 細胞（厚さ：約 $500 \mathrm{~nm}$ ）[8]における PLGA ナノ粒子の 取込挙動と類似している。現段階ではその理由は依然と して不明であるが, PLGA はエステル結合が生体内で加 水分解を受けるため, 生体吸収性に優れていることから 生体適合性が高い[18]ことが関係していると推察される。 以上の CLSM を用いた実験的検討より, PLGA ナノ粒子 は植物へ目的物質を送達するキャリア粒子として適して いることが示唆された。

\section{4. 結 言}

シロイヌナズナの葉と根に PLGA ナノ粒子を暴露した ときのナノ粒子の挙動を CLSM により直接観察を行っ た。その結果, シロイヌナズナの葉の表面に圧力をかけ ながら PLGA 粒子懸濁液を暴露すると, 気孔を通って葉 の内部に懸濁液が侵入し, 葉の内部に存在する葉肉細胞 にナノ粒子が取り达まれることがわかった。一方，シロ イヌナズナの根では, 細胞壁が薄い根の先端や根毛に PLGA ナノ粒子が取り达まれることがわかった。以上よ り, PLGAナノ粒子は植物においても目的物質を封入し て送達するためのキャリア粒子の基材として適している ことがわかった。

[謝辞］本研究は, JSPS 科研費 $15 \mathrm{H} 01745,15 \mathrm{KK} 0025$ の 助成により行われた。ここに記して謝意を表する。

\section{References}

[1] D. Y. Kim, A. Kadam, S. Shinde, R. G. Saratale, J. Patra, G. Ghodake, Recent developments in nanotechnology transforming the agricultural sector: A transition replete with opportunities, J. Sci. Food Agric. 98 (2018) 849-864.

[2] J. Popp, K. Peto, J. Nagy, Pesticide productivity and food security. A review, Agron. Sustain. Dev. 33 (2013) 243-255.

[3] Y. Liang, M. Guo, C. Fan, H. Dong, G. Ding, W. Zhang, G. Tang, J. Yang, D. Kong, Y. Cao, Development of novel urease-responsive pendimethalin microcapsules using silicaIPTS-PEI as controlled release carrier materials, ACS 
Sustain. Chem. Eng. 5 (2017) 4802-4810.

[4] R. Nair, S. H. Varghese, B. G. Nair, T. Maekawa, Y. Yoshida, D. S. Kumar, Nanoparticulate material delivery to plants, Plant Sci. 179 (2010) 154-163.

[5] G. Ru, L. Han, J. Qing, J. Sheng, R. Li, M. Qiu, J. Wang, Effects of borneol on the pharmacokinetics of 9nitrocamptothecin encapsulated in PLGA nanoparticles with different size via oral administration, Drug Deliv. 23 (2016) 3417-3423.

[6] A. S. Guedj, A. J. Kell, M. Barnes, S. Stals, D. Gonçalves, D. Girard, C. Lavigne, Preparation, characterization, and safety evaluation of poly(Lactide-co-glycolide) nanoparticles for protein delivery into macrophages, Int. J. Nanomedicine. 10 (2015) 5965-5979.

[7] J. Yang, Y. Zeng, Y. Li, C. Song, W. Zhu, H. Guan, X. Li, Intravascular site-specific delivery of a therapeutic antisense for the inhibition of restenosis, Eur. J. Pharm. Sci. 35 (2008) 427-434.

[8] K. Fukamachi, Y. Konishi, T. Nomura, Disease control of Phytophthora infestans using cyazofamid encapsulated in poly lactic-co-glycolic acid (PLGA) nanoparticles, Colloids Surfaces A Physicochem. Eng. Asp. 577 (2019) 315-322.

[9] M. Lakshmanan, Y. Kodama, T. Yoshizumi, K. Sudesh, K. Numata, Rapid and efficient gene delivery into plant cells using designed peptide carriers, Biomacromolecules. 14 (2013) 10-16.

[10] K. K. Ng, Y. Motoda, S. Watanabe, A. S. Othman, T. Kigawa, Y. Kodama, K. Numata, Intracellular delivery of proteins via fusion peptides in intact plants, PLoS One. 11 (2016) 1-19.

[11] C. Greene, S. J. Wechsler, A. Adalja, J. Hanson, Economic Issues in the Coexistence of Organic, Genetically Engineered (GE), and Non-GE Crops, Economic Information Bulletin
(2016) 1-34.

[12] Y. Kawashima, H. Yamamoto, H. Takeuchi, T. Hino, T. Niwa, Properties of a peptide containing DL-lactide/ glycolide copolymer nanospheres prepared by novel emulsion solvent diffusion methods, Eur. J. Pharm. Biopharm. 45 (1998) 41-48.

[13] M. M. Yallapu, B. K. Gupta, M. Jaggi, S. C. Chauhan, Fabrication of curcumin encapsulated PLGA nanoparticles for improved therapeutic effects in metastatic cancer cells, J. Colloid Interface Sci. 351 (2010) 19-29.

[14] K. Tahara, Y. Miyazaki, Y. Kawashima, J. Kreuter, H. Yamamoto, Brain targeting with surface-modified poly(d,1lactic-co-glycolic acid) nanoparticles delivered via carotid artery administration, Eur. J. Pharm. Biopharm. 77 (2011) $84-88$.

[15] R. Soffe, M. Bernach, M. N. P. Remus-Emsermann, V. Nock, Replicating arabidopsis model leaf surfaces for phyllosphere microbiology, Sci. Rep. 9 (2019) 1-12.

[16] F. Schwab, G. Zhai, M. Kern, A. Turner, J. L. Schnoor, M. R. Wiesner, Barriers, pathways and processes for uptake, translocation and accumulation of nanomaterials in plantsCritical review, Nanotoxicology. 10 (2016) 257-278.

[17] T. Nakagawa, Y. Konishi, T. Nomura, Introduction of biodegradable poly lactic-co-glycolic acid (PLGA) nanoparticles into yeast cells, J. Soc. Powder Technol. Japan 55 (2018) 626-630.

[18] Y. Nakano, T. Matoba, M. Tokutome, D. Funamoto, S. Katsuki, G. Ikeda, K. Nagaoka, A. Ishikita, K. Nakano, J. I. Koga, K. Sunagawa, K. Egashira, Nanoparticle-mediated delivery of irbesartan induces cardioprotection from myocardial ischemia-reperfusion injury by antagonizing monocyte-mediated inflammation, Sci. Rep. 6 (2016) 1-14. 